Från perestrojka till Bolotnaja. Utvecklingen av ett ryskt civilsamhälle specialnummer av Arkiv. Tidskrift för samhällsanalys, nr 7 (20I7)

\title{
Den sensovjetiska sociala mobiliseringen: neformaly-rörelsen under perestrojkan
}

\author{
Aleksandr V. Šubin (Shubin)
}

SAMMANDRAG: Den sensovjetiska sociala mobiliseringen karakteriserades av omfattande gräsrotsorganisering av grupper med olika ideologiska inriktningar och politiska preferenser. En av de mest inflytelserika miljöerna var den informella rörelsen, eller neformalyrörelsen, som bestod av sociala och politiska grupper (med allt från demokrater till anarkister, monarkister till socialdemokrater) som samarbetade med varandra inom ett brett spektrum av initiativ inom utbildning, kultur, miljöskydd, idrott etc. De distanserade sig både från staten och andra officiella sammanhang, och från de nya "demokratiska ledarna" som kom från de gamla partieliterna. De skapade horisontella organisationsprocesser och syftade till att mätta de existerande politiska strukturerna med ett nytt demokratiskt innehåll. Aleksandr Šubins artikel beskriver hur den informella rörelsen etablerades som en drivande kraft för utvecklingen av politisk pluralism och lade grunden för det civila samhället i Ryssland.

NYCKELORD: Sovjetunionen; perestrojka; social mobilisering; den informella rörelsen (neformaly-rörelsen); civilsamhälle; Ryssland.

PUBLICERINGSHISTORIK: Originalpublicering.

ALEKSANDR V. ŠUBIN är professor i historia och senior forskare vid Institutet för allmän historia vid Ryska vetenskapsakademin.

E-POSTADRESS: shubinav@mtu-net.ru

FÖRSLAG PÅ KÄLLANGIVELSE:

Šubin, Aleksandr V. (20I7) "Den sensovjetiska sociala mobiliseringen: neformaly-rörelsen under perestrojkan", i Från perestrojka till Bolotnaja. Utvecklingen av ett ryskt civilsambälle, specialnummer av Arkiv. Tidskrift för sambällsanalys, nr 7, s. 27-55. DOI: https://doi.org/I0.13068/2000-62I7.7.I

(C) Aleksandr V. Šubin/Arkiv förlag \& tidskrift 2017 (publicerad 8 februari 20I7)

Artikeln distribueras enligt en upphovsrättslicens från Creative Commons:

Erkännande-Ickekommersiell-IngaBearbetningar 3.0 Unported, som medger fri ickekommersiell användning och spridning i oförändrat skick så länge källan anges. 
Arkiv. Tidskrift för samhällsanalys är en sakkunniggranskad vetenskaplig tidskrift för samhällsvetenskap och historia. Samtliga artiklar publiceras fritt tillgängliga på:

$$
\text { www.tidskriftenarkiv.se }
$$

Beständig länk, DOI: https://doi.org/IO.I3068/2000-62I7

Den här artikeln finns tillgänglig i följande format:

PDF \& HTML: via beständig länk, DOI: https://doi.org/IO.I3068/2000-62I7.7.I EPUB: ingår i e-boksutgåva av numret, ISBN: 978 9I 7924283 I TRYCK: ingår i bokutgåva av numret, ISBN: 978 9I 79242848

Grafisk utformning och sidnumrering är identisk i pdf och tryck.

Samtliga artiklar i nr 7 (20I7), Från perestrojka till Bolotnaja. Utvecklingen av ett ryskt civilsamhälle, nås via beständig länk, DoI: https://doi.org/IO.I3068/2000-6217.7

REDAKTÖR FÖR NUMRET: Zhanna Kravchenko

Arkiv. Tidskrift för samhällsanalys ISSN: 2000-62I7 (för elektronisk resurs) ISSN: 2000-6225 (för tryckta nummer)

ges ut av

Stiftelsen Arkiv för främjande och spridning av samhällsvetenskaplig och historisk forskning

genom

Arkiv förlag \& tidskrift

Box 1559

SE-22I OI Lund

ВESÖK: L Gråbrödersg 3 c, ipg

TEL: 046-I3 3920

ARKIV FÖRLAG: arkiv@arkiv.nu·www.arkiv.nu

TIDSKRIFTEN ARKIV: red@tidskriftenarkiv.se · www.tidskriftenarkiv.se

ANSVARIg UTGIVARE \& CHEFREDAKTÖR: Sven Hort

ADMinistrativ RedAKTÖr: David Lindberg ReDAKTörer: Paavo Bergman, Lisa Kings, Zhanna Kravchenko 


\title{
Den sensovjetiska sociala mobiliseringen: neformaly-rörelsen under perestrojkan
}

\author{
ALEKSANDR V. ŠUBIN
}

När återuppstod det ryska civilsamhälle som hade ryckts upp med rötterna genom Stalinregimens efterrevolutionära ansträngningar? När uppkom det nätverk av statsoberoende och icke-kommersiella organisationer och rörelser som, trots alla svårigheter, existerar än i dag och till och med, vilket stod klart under händelserna 20II-20I2, är i stånd att ta strid med den ryska auktoritarismen? Som vi ska se kan man till och med peka ut datumet för det moderna civilsamhällets födelse i Ryssland. Det rör sig förstås om tiden för perestrojkan, när civilsamhället inte bara återuppstod utan även antog sina huvuddrag och väsentligen kom att påverka den politiska kulturen i Ryssland som helhet. Denna process är förknippad med den företeelse som då fick benämningen "neformaly" - de informella politiska rörelserna. Syftet med denna artikel är att beskriva de informella politiska gruppernas historia, så långt det är möjligt att rekonstruera den på grundval av de hågkomster och dokument som bevarats från perestrojkan.

\section{Samhällsrörelsernas tre vågor}

Av utrikespolitiska skäl fattades i december 1986 det politiska beslutet att avstå från rättsliga åtgärder mot oliktänkande i Sovjetunionen. $\mathrm{Nu}$ kunde man berövas sitt arbete för att man uttalat oppositionella åsikter, men inte sin frihet. Detta erbjöd naturligtvis inte de oliktänkande några 
som helst politiska friheter eller ens garantier mot framtida åtgärder, men det skapade likväl förutsättningar för en aktivering av samhällslivet. Vid denna tid fanns det redan samhällsorganisationer som var oberoende av Sovjetunionens kommunistiska parti (SUKP), men de utgjorde inget gemensamt system. Den politiserade dissidentrörelsen var ett isolerat och vid denna tidpunkt redan nära nog krossat fenomen (den skulle heller aldrig hämta sig från repressionerna). Och de informella rörelserna hade en apolitisk karaktär, som sång-, bildnings- och litteraturklubbar, naturskyddsföreningar etc.

Vid en första anblick ställer den dissidentiska, informella och demokratiska rörelsen upp sig i en ordningsföljd som liknar den välkända Leninska för den ryska revolutionsrörelsens tre generationer, och som speglar olikheterna i de historiska omständigheterna för den politiska

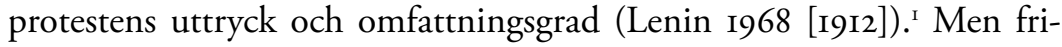
hetsrörelsens utveckling var i praktiken inte linjär. Uppluckringen av det kommunistiska systemet ledde till att de informella miljöerna formerades tidigare än de dissidentiska - redan på 1950-1960-talen (för detaljer se Šubin 2008).

Med perestrojkans inledning verkade det dock som att dissidenternas stora ögonblick var kommet. De kom ut ur lägren och fängelserna. Men någon dissidentrörelse etablerades inte under 1960-1980-talet - flertalet av dess ledare var redan alltför trötta på kampen. Några människorättskämpar blev tillräckligt kända i väst för att fullständigt kunna byta farorna och vedermödorna med livet i Sovjetunionen mot en lugn och bekväm ålderdom i utlandet. Efter 1986 tappades dissidentrörelsen på blod genom emigrationen, men även bortsett från människorättskämpar som Andrej Sacharov hade den behov av en längre vilopaus och till sin största del bedrev den ingen aktiv politisk verksamhet fram till I988. Undantag utgjordes av några aktivister som anslöt sig till den informella rörelsen (bland annat Valerija Novodvorskaja och Lev Timofeev) eller

I. Författaren refererar mer specifikt till Lenins periodisering av den ryska revolutionen som en följd av tre klassbaserade generationer av adel och landägare, raznočincy (ofrälse tjänstemannaklass) och proletariatet. Dessa tre faser var kopplade inte bara till revolutionärernas klassbakgrund utan även till deras ideologi och handlingsmetoder. Det gäller först och främst narodniker (se not 3 nedan) och socialdemokrater, som tillhörde medelklasskikten, inte proletariatet. Red. anm. 
tack vare sin status och position kunde få tillträde till officiella publiceringskanaler ${ }^{2}$ (Roj Medvedev och Igor Šafarevič bland dem). Paradoxalt nog satte slutet på förföljelserna punkt även för dissidentrörelsens historia. I kraft av förändringarna i landet påbörjades en period av hegemoni för de informella grupperna inom det civila samhället. "Informella" kallade man från början ett mycket vitt spektrum av sociokulturella ungdomsinitiativ och strömningar som inte kontrollerades av SUKP och staten, från filatelister och rockmusiker till punkare och hippier. Men redan 1987 "klibbade" ordet fast vid de sociala och politiska initiativen. Det är helt naturligt - perestrojkan var en tid av politisering. Med informella grupper kommer vi därför i det följande just avse de sociala och politiska informella grupperna.

Dissidenter, informella och demokrater representerar tre vågor i en samhällsrörelse som karakteriserades av olika egenskaper. Dissidenterna utmärktes av att prioritera den människorättsliga tematiken samt av ett "tabu" både mot att samarbeta med myndigheterna och att tillämpa våld. De liberala kommunisterna, det framtida "demokratiska ledarskiktet", vars ledare tillhörde den statusladdade intelligentian och den "upplysta" delen av byråkratin, orienterade sig mot att genomföra reformer i samarbete med och till och med underställda den del av den styrande eliten som delade demokratins ideologiska postulat (ofta negativa - antibyråkratiska och därefter antikommunistiska, antinationalistiska). Om man betraktar de informella som fenomen i sin helhet, så uppvisade de väldigt få tabun och begränsningar. Oavsett det faktum att varje ickeofficiell grupp hade sina myter, stereotyper och "tabun", så existerade praktiskt taget ingen gemensam ideologisk kontur, med undantag för principerna om icke-våld som man hade gemensamma med dissidenterna och som flertalet delade.

I informella sammanhang umgicks demokrater, patrioter, anarkister, monarkister, kommunister, socialdemokrater och liberalkonservativa av olika schatteringar förhållandevis lugnt. De informellas gruppbildningar skedde ibland inte alls utifrån ideologiska principer, utan utifrån inriktningen på deras verksamhet: försvarare av kulturminnes-

2. Det vill säga de bokförlag, tidningar och tidskrifter som staten hade kontroll över. Red. anm. 
märken, folkbildare, naturskyddsvänner etc. De politiskt informella tillmätte dock de socialt informella initiativen strategiska visioner för framtiden och propagerade utifrån än en nationalpatriotisk position, som föreningen "Minne" (Pamjat'), än en vänsterinriktad position (som marxister och ny-narodniker ${ }^{3}$. 1986-1987 framträdde för första gången de politiserade informella grupperna (i regel kallades de för klubbar) utan någon iögonfallande ideologisk fasad: "Klubben för sociala initiativ" (Klub socialnych iniciativ), ”Den korresponderande (därefter Allunionella) socialpolitiska klubben" (Zaočnyj (därefter Vsesojuznyj) social'no-političeskij klub), "Perestrojkaklubben" (Klub Perestrojka). Deras uppgift vara att etablera kontakter mellan oppositionellt orienterade aktivister. I dessa tidiga klubbar fann företrädare för närbesläktade åsikter varandra. Därefter, från och med mitten av 1987, "kläcktes" mer ideologiskt färgade grupper ur dessa: den liberala "Medborgerlig värdighet" (Graždanskoje dostoinstvo), den marxistiska "Socialistiskt initiativ" (Socialističeskaja iniciativa), den socialdemokratiska "Demokratisk förändring" (Demokratičeskaja perestrojka) ${ }^{4}$, den ny-narodniska "Gemenskap" (Obščina) med flera.

De informella kan med lätthet avskiljas från såväl den dissidentiska som allmändemokratiska rörelsen. Till skillnad från dissidenterna var de informella öppna för att samverka med myndigheterna och ingå i statliga och halvofficiella strukturer. Till skillnad från "demokraterna” ställde sig de informella skeptiska till perestrojkans erkända "byggmästare" och de "demokratiska ledarna" från de gamla styrande eliterna, de föredrog att verka i mindre grupper, och splittrade sålunda ständigt den "demokratiska fronten". De informella föredrog att placera någon konkret social verksamhet i centrum för sin aktivitet, trots att alla informella grupper hade sin egen, stundom högst exotiska ideologi. De informellas ideologism tillät inte denna miljö att komma överens om enhetliga ideologiska

3. Narodnikerna var en rysk populistisk social rörelse med sin bas i medelklassen i slutet av I800- och början av I900-talet som menade att jordbruket skulle utgöra grunden för samhällsekonomin och bondesamhället förebild för samhällsbildningen, samt förespråkade en allians mellan intelligentia och bönder (narod). Red. anm.

4. Både den moderata Demokratičeskaja perestrojka och den radikalt liberala gruppen Perestrojka-88 hade sitt ursprung i den ovan nämnda Perestrojkaklubben som I988 splittrades efter dessa båda linjer (Igrunov 1989). Red. anm. 
principer, samtidigt som dissidenter och demokrater med lätthet lyckades komma överens om "det mest grundläggande". De informella karakteriseras av förbindelser av övervägande horisontell karaktär (till skillnad från den demokratiskt-populistiska rörelsen och senare tiders partistrukturer). Trots sin livslängd dominerade den informella miljön bara den oppositionella rörelsen under perestrojkans inledande etapp, och blev en utlösande faktor för formerandet av det civila samhället, men inte för det nya maktsystemet. Som ett resultat uppstod en typ av arbetsfördelning: "demokraternas" ledare satsade på att omforma samhället uppifrån och de informella underifrån. Resterna av dissidentrörelsen "kom" antingen "till makten", och avstod från tidigvarande människorättsprinciper, eller bevarade sin människorättsliga inriktning och stannade kvar i det civilsamhälleliga systemet.

I den situation av kris för de ekonomiska reformerna som rådde $\mathrm{i}$ början av 1990-talet var de "demokratiska" ledarna inriktade på att successivt likvidera sovjetsystemets demokratiska fasad och samtidigt forma om de reella maktinstitutionerna efter västerländsk modell. De informella strävade, tvärtom, mot att mätta fasadstrukturen (med samverkansråd, fackföreningar och andra sociala organisationer) med ett reellt innehåll, vilket skulle göra det möjligt att riva ner de faktiskt auktoritära institutionerna - framför allt de partibundna.

\section{En konstruktiv pluralism}

Psykologin hos den första generationen politiskt informella formerades under ett successivt utträde ur källarhålet I986-1988 och en stegvis vidgning av utrymmet för de politiska och medborgerliga friheterna. Dessa friheter uppnåddes genom ett "egenmäktigt förfarande", under vilket oppositionen kände efter hur långt makten var redo att ge vika: Kan man nu uttala sig mot den kommunistiska praktiken från Lenins dagar på en statlig läroanstalt - eller fortfarande endast kritisera Stalin, och göra antydningar om den samtida kommunistregimen? Hade tiden kommit för att planera en gatudemonstration, eller skulle det vara meningslöst, eftersom den genast skulle slås ner av myndigheterna? Samtidigt var man i början tvungen att verka i full isolering, med en känsla av att man stod 
ensam mot makten, och utarbeta en ideologisk ståndpunkt i en situation som präglades av brist på politisk information.

De informellas klubbar bestod av kärnor och periferier. I kärnan umgicks ett tiotal personer så gott som dagligdags, energiskt dryftande de politiska nyheterna och det förflutnas "vita fläckar", en möjlig reaktion på det som höll på att ske, möjligheter att skynda på förändringarna och ge dem en ur klubbens synvinkel nödvändig inriktning. Detta liv var intressant och uppfyllande, ibland till och med utmattande. Deltagarna hade ibland inte utan grund intrycket att de kunde påverka storpolitikens förlopp. Gruppens periferi bestod av sådana som tyckte om att närvara vid de informellas evenemang - föreläsningar på förbjudna teman, teaterföreställningar där Bakunin, till salens applåder, debatterade med Marx. Mellan kärnan och periferin skapades inledningsvis ett "aktör-åskådare"förhållande, där aktören försågs med såväl berömmelsens strålglans som med skeptiska repliker, och åskådaren med intryck. Showen politiserade likväl åskådaren, och drog, från kampanj till kampanj, först in periferin i utförandet av enskilda uppdrag och därefter även i verkligt farliga handlingar, såsom deltagande i otillåtna sammankomster eller att föra in flygblad på något militärförband. Genom sitt beslut att delta i oppositionella handlingar förvandlades man till en del av kärnan. Men eftersom ett långvarigt deltagande i kärnans liv snabbt slet ut många av deltagarna, drog de sig ofta därefter ur rörelsen utan att återvända till periferin. En kvalitativ skillnad mellan denna politiska miljö och partilivet vid sekelskiftet tjugohundra var att allt arbete var obetalt.

Resultatet av de informellas arbete blev en faktor i storpolitiken 1988 I989 när SUKP, till sin egen överraskning ställdes inför manifestationer i vilka tusentals och senare hundratusentals människor deltog. Oppositionen formerade organisationsstrukturer och utarbetade detaljerade program för en omstrukturering av samhället. Detta tiotal sociopolitiska organisationers uppkomst och utträde ur källarhålet ledde ofrånkomligen till uppkomsten av ett politiskt fält - ett system av samverkande politiska kärnor som arbetade i olika ideologiska riktningar. Det var ju faktiskt just avsaknaden av ett sådant fält i Sovjetunionen som hade hindrat uppkomsten av ett fullgånget civilsamhälle. Dess beståndsdelar människorättsliga, sociala och informativa organisationer - var redan 
för handen, men något gemensamt politiskt fält existerade ännu inte. En majoritet av de informella organisationerna insåg att riktningen bara kunde få någon betydande framgång i förening med besläktade grupper på alla flanker. Därför förde de sociala klubbarna redan från början en kamp för att i regel kring sig själv samla koalitioner och allianser med sikte på att skapa allunionella organisationer. Men för att man skulle fördelas över det politiska spektrumet måste man först skapa just detta spektrum och genomföra ett möte med de befintliga informella organisationerna.

20-23 augusti 1987 genomfördes mötet "Samhälleliga initiativ i perestrojkan" (Obščestvennyje iniciativy v Perestrojke) i Moskva. Företrädare för femtio klubbar från tolv stora städer samlades - i salen satt fler än 300 personer. Detta möte tillät de informella att etablera ett omfattande kontaktnät. Det är i själva verket först från denna stund man kan tala om ett enhetligt fält av statsoberoende samhällsrörelser - ett för Sovjetunionen tidigare okänt fenomen. Om man talar om civilsamhället, inte som summan av isolerade strukturer, utan som ett inbördes sammankopplat system som verkar öppet på det sociopolitiska området, så är det sovjetiska civilsamhällets födelsedatum 23 augusti 1987 (för detaljer se Šubin 2006). På mötet skapades det första allunionella protopartiet: "Federationen för de socialistiska samhällsklubbarna" (Federacija socialističeskich obščestvennych klubov, FSOK). I988 uppstod ytterligare några protopartier: "Demokratiska förbundet" (Demokratičeskij sojuz), "Socialekologiska förbundet" (Social'no-ekologičeskij sojuz) med flera. De politiskt informella började ingå i olika koalitioner och skapa system för en oberoende press och skydd av arbetarnas rättigheter, samt upprätta kontakter med de informella rörelserna och initiativen för territoriellt självstyre.

Fram till maj 1988 slutfördes den inledande fasen i formerandet av det politiska spektrumet - grunderna till ett flerpartisystem uppkom i landet. De nya politiska organisationerna var inte partier i ordets klassiska bemärkelse och det är därför mer korrekt att kalla dem just protopartier. De utgjorde ett vitt idémässigt spektrum. De radikala liberala idéerna förespråkades av Demokratiska förbundet som skapades den 8 maj I988, och som ansåg det nödvändigt att, i såväl Ryssland som de 
andra sovjetrepublikerna, snarast upprätta ett samhällssystem liknande det som fanns i väst. Denna position försvarades även av de andra liberala grupperingarna, såsom Medborgerlig värdighet, men de ansåg att man måste gå successivt fram. Ett flertal organisationer gjorde sig till förespråkare för socialismens idéer, men de hade en väldigt disparat förståelse av dem. Några, såsom Socialistiskt initiativ, ansåg det nödvändigt att återupprätta de sanna marxistiska principer som hade kränkts av Stalinbyråkratin. Andra, såsom Gemenskap (vilken uppstått i maj 1987), motsatte sig marxismen och förfäktade narodniska idéer om lokalt självstyre. Trots dessa skiljaktigheter ingick både Gemenskap och Socialistiskt initiativ i Federationen för de socialistiska samhällsklubbarna. Men de informella ansåg att landets öde var avhängigt av riktigheten i deras reformstrategier, på samma sätt som detta öde hade berott på ledarna för de antibolsjevikiska partierna i början av 1900-talet. Det var därför svårt att jämka samman de informella gruppernas ståndpunkter. I debatterna mellan dem framarbetade man samtidigt såväl erfarenheterna som grunderna till det framtida Rysslands politiska kultur. Oavsett alla inbördes motsägelser såg alla dessa rörelser sin motståndare i nomenklaturan, för vilken det inte fanns någon plats i ett demokratiskt samhälle. Samtidigt förespråkade nästan alla informella aktivister icke-våldsmetoder i kampen mot den kommunistiska regimen. Boris Kagarlickij kunde med full rätt deklarera: ”Det verkar som om vi inte bara har en åsiktspluralism, utan faktiskt också en politisk pluralism framför oss. Vi bevittnar tillblivelsen av ett spektrum av informella förbund, formerandet av nya strömningar” (Kagarlickij i Jušenkov 1990). Det rörde sig inte så mycket om en juridisk tillblivelse (yttre lagstiftning), som om en inre medvetenhet om vikten av ett av makten och den allmänna opinionen oberoende idéskapande.

De informella organisationernas värld 1987-1988 är en alldeles egen slags modell för det demokratiska samhället i vilken deltagarna "spelade med i storpolitiken", lade energi på kampen om platser i "koordinationsorganen" och försvarade varje punkt i de politiska programmen som om det vore ett grundlagsprojekt de hade utarbetat. Och i detta låg den politiska betydelsen, eftersom de informella snart lärde sig att föra ut de allvarstyngda människomassorna på gatorna och deras publikationer omvandlade glasnost till yttrandefrihet. Detta var en exempellös trä- 
ning genom vilken hundratals blivande politiska ledare, journalister och andra samhällsaktörer på ett fåtal år tillägnade sig den politiska kulturen från samhällen med långvariga demokratiska traditioner. Efter att ha genomfört det organisatoriska och ideologiska arbetet i maj 1988, satte de informella politiska grupperna upp en övergång till politisk handling på dagordningen. Och inom kort skulle en möjlighet visa sig som de informella i mångt och mycket själva hade skapat.

\section{Utträdet på gatorna}

Det var valet till SUKP:s nittonde partikonferens, som skulle hållas i juni 1988, som fick ut folket på gatorna. Det påminner om inledningen på den demokratiska rörelsen i december 20II, som föranleddes av valen till duman i vilka partier illojala mot Putin inte kunde delta, men som likväl inte kunde försiggå utan valfusk till förmån för det parti, Enade Ryssland (Edinaja Rossija), som står Kreml närmast (se Sachnin i detta nummer). Även om flertalet av de informella inte var medlemmar i SUKP, sympatiserade de med den progressiva reforminriktade falangen av partiet. Men SUKP:s konservativa provins- och stadsdistrikt valde obekanta "liberala" kommunister till partiforumet. SUKP uppfattades fortfarande som samhällets styrande struktur och valet till partikonferensen var en repetition inför parlamentsvalet. Missnöjet med "valet utan val" blev anledning till de första massmötena mot de lokala partibossarna i Juzjno-Sachalinsk 2I maj 1988, och därefter i Omsk, Samara och Astrachan. Provinsmötena, som var riktade mot ledarna för de regionala partiorganisationerna, markerade inledningen på den process som skulle fortgå ända till valet till folkkongressen 1989 - ett utbyte av de gamla kadrerna mot nya, mer flexibla kommunistledare. Eftersom aktiverandet av samhällsrörelsen gick olika fort i Rysslands olika regioner, fortgick de uppblossande proteströrelserna mot distriktskommittéernas förstesekreterare till 1990. De regionala "upprorens" uppflammande, icke-koordinerade karaktär gjorde dem förhållandevis ofarliga för centrum och gjorde det till och med lättare att avsätta de konservativa ledarna som "oförmögna att hantera" befolkningen. Betydelsen av lokala demonstrationer var alltid mindre om protesten inte överfördes till huvudstaden. 
På våren 1988 kom de informella grupperna fram till slutsatsen att det var nödvändigt att utveckla en kampanj för demokratiska politiska massmanifestationer, vilka inte bara skulle engagera de informella grupperna själva, utan även personer som tidigare inte tillhört oppositionen. Samhällets uppdämda missnöje med de bromsade reformerna kunde enligt ledarna för rörelsen genom denna kampanj ha inverkan på den politiska kursen. Den 28 maj 1988 påbörjades möteskampanjen i Moskva och Leningrad och den visade sig bli långvarig i Moskva och genomfördes genom oppositionsforum som var kopplade till reformister i toppskiktet. Folket gick ut på gatorna men för de informella grupperna blockerades vägen dit av de "temporära regler" om genomförande av möten som antagits 1987 och som förbjöd "icke-sanktionerade" manifestationer. För att hålla sig inom lagens råmärken var man tvungen att erkänna kommunistpartiets auktoritära regims rätt till monopol på politiskt handlande.

I februari 1988 försökte Medborgerlig värdighet pröva den formella procedur som regelverken föreskrev, och, såsom det hade varit för de informella redan under "Jeltsinkrisen" i november 1987,5 så fick även de avslag. En ny ansökan lämnades in 5 mars - på Stalins dödsdag. Avslaget kom under ett protestmöte, vilket gjorde intryck av provokation - men folk var redan underrättade:

Avslaget motiverades av att demonstranterna skulle ha framfört slagord ("Glasnost är en garanti mot stalinismens återupprättande", "En fortsatt utveckling av det samhälleliga och politiska livet i Sovjetunionen") som påstods bära på en samhällsfientlig karaktär och skadade demokratiseringsarbetet i vårt land (Chronika obščestvennogo dviženija 1988, s. 4).

Ledarna för Medborgerlig värdighet var bortgjorda. De mer radikala grupperna, "Demokrati och humanism" (Demokratija i gumanizm) och "Perestrojka-88", som hade förespråkat mer resoluta handlingar, strödde salt i deras sår. På Stalins dödsdag hade de genomfört en icke-sanktionerad "sammankomst" på Oktobertorget under slagorden "En fullständig destalinisering av samhället" och "Res minnesmärken över repressionens offer”. De lyckades inte få till stånd något politiskt protestmöte, men det

5. I november 1987 blev Boris Jeltsin avskedad från sin position som lokal partichef för SUKP i Moskva i ett försök att utestänga honom från aktivt politiskt inflytande. Red. anm. 
ingick inte heller i de radikala aktivisternas planer. Några tiotal informella höjde emellanåt sina plakat och försökte få någonting sagt, varpå de genast eskorterades in i en polisbuss. Resten skyfflades undan från gatorna med hjälp av snöröjningsmaskiner. Detta bevittnades av några hundratal förbipasserande. Så skapades Demokratiska förbundets protestmöteskultur, i vilken polisens handlingar i sig själva blev ett väldigt viktigt agitationsmedel.

Men för att kunna utlösa en sådan värdefull reaktion på den politiska mötesrevolutionen måste man genomföra en aktion som myndigheterna åtminstone till en början inte kunde upplösa. Medborgerlig värdighet beslutade att de måste genomföra en massiv gatuaktion utan myndigheternas tillstånd i akt och mening att de omgivande människorna skulle kunna komma i kontakt med de informella på samma politiska våglängd. Resultatet skulle komma att bli ett slags "Hyde Park" i Moskvas centrum. Men därtill behövde Medborgerlig värdighet hitta allierade för att en betydande massa informella omedelbart skulle kunna gå ut på gatorna. De ideologiskt närstående Demokrati och humanism och Perestrojka-88 lämpade sig inte för detta - deras demonstrationsstil var inte inriktad på dialog med befolkningen, utan snarare på att chockera. Sökandet efter allierade varade i två månader och till slut fann man dem i medlemmarna i klubben Gemenskap.

Gemenskap hade på sitt håll fått möjlighet att organisera ett protestmöte tillsammans med miljöaktivisterna. "De gröna” (Zelënyje) framkallade minst farhågor i partiledningen och kunde därför utgöra gatudemokratins förtrupper. I mars genomfördes ett protestmöte av försvararna av Bitsevskijparken. Gemenskap etablerade då kontakt med De gröna och började delta i organiserandet av miljömanifestationer, och samtidigt politiserade man dem. Den I2 maj 1988 samlades miljöaktivistorganisationen framför Moskvas stadshus (Mossovjet). För att inte protestmötet skulle svälla ut över sina bräddar bjöd myndigheterna in de informella i stadshuset till ett möte med ordföranden för den verkställande kommittén. De aktivister i Gemenskap som deltog i protesten och mötet utvecklade, med stöd av miljöaktivisterna, den polemik med "stadens fäder" som föranletts av" de temporära reglerna", vilka inte tillät miljöaktivisterna och andra medborgare att demonstrera sin åsikt. 
Denna erfarenhet inspirerade Gemenskap till att förbereda en politisk massmanifestation. Och här bereddes man ett utmärkt tillfälle att lära känna ledarna för Medborgerlig värdighet som brottades med samma problem. De icke-sanktionerade demonstrationernas huvudkrav var demonstrationsfriheten som sådan - det vill säga att de "temporära reglerna” skulle upphävas. Man avsåg att skapa en frihet efter eget skön och redan under protestmötet tala om vad man ville: lägga fram politiska program, dryfta den rådande politiska situationen, inklusive valet till partikonferensen. De informella grupperna behandlade snarast valet till konferensen som en förevändning att kritisera SUKP. Valets odemokratiska karaktär var ett bevis på hur odemokratiskt det styrande partiet var. "Vårt förhållande till liberalkommunisterna inför protestmötena kunde definieras av Lenins fras: 'Kämpen proletärer, bourgeoisien håller på att sno åt sig makten."”6 Men viljan att dra ytterligare uppmärksamhet till demonstrationen och utöva inflytande på kampens förlopp i toppskiktet gjorde sitt - ett av demonstrationens slagord var "Jämlika val till konferensen!" Andra slagord ägnades åt de informella gruppernas program.

I980-talets första demokratiska massdemonstration, den 28 maj I988, förbereddes omsorgsfullt. Deltagarna samlades i hemlighet på tre platser och gick på avtalad tid ut på torget framför Bolsjojteatern där de möttes av på förhand informerade korrespondenter. Den oberoende åskådaren Sergei Mitrochin skildrar det som inträffade så här:

Den 28 maj är ett datum som redan nått berömmelse genom namnet Mathias Rust och det kommer att gå till historien som en helgdag, vars namn är - demokratins utbrott [... I5:55. På den öppna platsen framför Bolsjojteatern samlas de mest skiftande informella grupper [...] i6:00. Demonstranterna tar på organisatörernas (Isaev, Šubin, Zolotarëv) uppmaning effektivt plats på Bolsjojteaterns trappsteg. Bland leden vecklas till allmän upphetsning (men delvis också chock) anarkins svarta fana ut med en röd stjärna fastsydd i mitten. Till de förbigåendes och de många tevefotografernas åskådan ställs plakat fram med slagorden: "All makt åt råden!", "En socialism för folket och inte ett folk för socialismen”, "En socialism på kooperativ grund" (Mitrochin I988).

Polisen dök upp och började stänga av utgången mot Gorkijgatan. Men plötsligt "försvann" demonstrationen. Leden om exempelvis 200 per-

6. Vladimir Gurbolikov i samtal med författaren. 
soner rörde sig inte rakt fram till Gorkijgatan utan genom sidogatorna. Det var bara ett fåtal meter kvar till utträdet på det "operativa spelrummet" när vägen blockerades av tre polismän med megafoner. Befälet frågade: "Vem är ledaren?” Det uppstod förvirring. Viktor Zolotarëv kastade sig i skottgluggen och presenterade sig som ledaren. Polisen kallade in honom i bilen. Då började demonstranterna sjunga revolutionssången "Warzawjanka" och utnyttjade sitt numerära överläge till att kringgå polisavspärrningen. Polisen släppte Zolotarëv och leden strömmade ut på Moskvas huvudgata. Protestmötesrevolutionen hade börjat. Mitrochin fortsätter:

Processionen satte sig i rörelse och uppvisade en ytterst brokig syn för den förstummade invånaren på gatorna i centrum: längst fram och utmed ledets flanker rör den sig med kräftgång och viker på ett ofattbart sätt undan med hela kroppen, filmteamen börjar knuffas och trängas. Processionen leds av Andrej Isaev. Han skrider insmickrande fram och griper med en aning sänkt huvud tag i handtaget på en svart processionsfana. ${ }^{7}$ I hans kölvatten bär fem eller sex personer - på tillbörligt avstånd från ledaren - på en röd banderoll med gula bokstäver: "Frihet utan socialism är ett privilegium och en orättvisa, socialism utan frihet är ett slaveri och en svinaktighet" [...]

Därefter inleder vi en egenartad politisk badmintonmatch. En ljudlig stämma utropar påträngande (bokstavligen framslungande) en dagsaktuell fras i dativkasus: "Åt perestrojkan ...!" - och de förberedda medspelarna parerar denna serve med ett enkelt och enstavigt "Ja!", ”Åt byråkratin ...!" - ”Nej!", ”Åt konstitutionen ...!" - ”Ja!", ”Åt de temporära reglerna ...!" - ”Nej!” (Mitrochin I988).

De förbipasserande reagerade på olika sätt och väldigt emotionellt på denna för tiden otroliga handling. En kvinna skrek: "Ska de göra så här i vår sovjetiska tid!" Man diskuterade livligt vad de svarta fanorna kunde betyda - piratflaggor kanske. Två krigsveteraner anslöt sig till processionen med orden: "Framåt marsch, grabbar, ända till Berlin!" Längs vägen fick demonstrationen påfyllning av människor som råkade gå förbi och som gick lite vid sidan om, nyfikna på hur det skulle sluta.

7. Mitrochin misstar sig. På de fotografier som togs av filmteamen kan man se att Isaev bar en röd fana. De svarta fanorna bars av anhängarna till Gemenskap. I sin skildring ”överräcker” Mitrochin den röda fanan till Isaev närmare processionens slut för att på så vis demonstrera hans "opportunism". 
På Pusjkintorget ägde sedan ett för tiden stort protestmöte rum - det pågick en halvtimme och hade ett tusental deltagare. Protestmötet blev början på en serie varje vecka upprepade demonstrationer som pågick till den I8 juni 1988 och blev kända som "Hyde Park". Samma dag samlade Demokratiska förbundet ett protestmöte för flerpartisystem framför Kazankatedralen i Leningrad. Efter att ett antal deltagare i protestmötet hade blivit arresterade, tågade de informella i en demonstration förbi polisstationen sjungande "Internationalen" och "Warzawjanka". De arresterade släpptes. Framför Kazankatedralen uppstod Leningrads "Hyde Park". Processen hade satts i rullning.

De anföranden som från och med den 28 maj hölls vid de återkommande protestmötena i Moskvas "Hyde Park" varje lördag hade väldigt varierade teman - från den aktuella politiska situationen och reformprogrammen till händelserna i Novotjerkassk 1962. ${ }^{8}$ Man propagerade för idén om en "folkfront" (narodnyj front) som ska behandlas nedan. På mötena framträdde företrädare för flertalet av huvudstadens informella organisationer, och bland åhörarna fanns många framtida politiska kändisar, inklusive Vladimir Zjirinovskij, Sergei Jušenkov och Sergei Stankevič (Jušenkov I99I, I990; Rjabov 1988). Efter själva mötet brukade åhörarna dela upp sig i en mängd mindre klickar och det dröjde länge innan man skingrades.

I "Hyde Park" uppkom ett gatans verkliga "parlament" (i den ursprungliga betydelsen av samtal eller rådplägning, besläktat med dagens franska parler, "att tala") som föregrep det som skulle hända med Rysslands politiska liv några år senare. Man talade om allt som gnagde och mognade. Men samtalet var trots detta inte kaotiskt. Protestmötena leddes av dem som tog initiativ till anförandena och av ett "presidium" som reglerade diskussionens förlopp, på bekostnad av ledarna för de informella grupper som beslutat sig för att inte delta i demonstrationen den 28 maj. Bakom "presidiet" stod en ny framväxande organisation -

8. I juni 1962 bröt en strejk ut på en lokomotivfabrik i staden Novotjerkassk som snabbt spred sig och övergick i kravaller. Bakgrunden var dåliga arbetsförhållanden och prishöjningar på livsmedel. Militären kallades in och i konfrontationen som följde dödades uppskattningsvis 26 demonstranter av soldaternas kulor. Händelsen har blivit känd som massakern i Novotjerkassk. Red. anm. 
"Folkfrontens organisationskommitté" (Orgkomitet Narodnogo fronta), sammansatt av, och på bekostnad av, de grupper som hade bildats eller trätt ut på den samhälleliga arenan under protestmötenas lopp. Diskussionerna i organisationskommittén blev en form av "andra kammare" i detta "parlament", där man förberedde de definitiva besluten som man också gett röst åt på protestmötena. Viktor Zolotarëv skriver:

Protestmötet 28 maj och de åtföljande tre junimötena innebar i själva verket inledningen på "Hyde Park" på Pusjkintorget. För efter dessa protestmöten kom den politiska kommunikationen igång av sig själv. Företrädare för olika grupper började strömma till Pusjkintorget och skänka (och senare sälja) litteratur till varandra. Parallellt med detta växte intresset för tidningen Moskovskije Novostis stånd. Allt detta sammantaget lade grunden till det "Hyde Park" som skulle existera i ett par år (Zolotarëv 2005).

I slutet av augusti och början av september ägde ett nytt utbrott av politisk konfrontation rum på Pusjkintorget vilket hade initierats av Demokratiska förbundet. Aktivisterna i Gemenskap gillade inte manifestationernas konfrontatoriska linje, eftersom oppositionen då inte kunde framföra sina åsikter. De kom till Demokratiska förbundets möten och bedrev propaganda i protestmötets periferi, och råkade ibland också själva i trubbel (på så vis hamnade jag själv i häktningscellen den 5 september, men lyckades i domstolen utverka friande dom). En av Gemenskap-aktivisterna, Rjabov, karakteriserar betydelsen av sommarens tilldragelser så här:

Man vill visa på faran för att krisen ska utveckla sig i en oförutsägbar riktning - när man klämmer åt folk definitivt och berövar dem möjligheten att lagligt tillgripa demonstrationer, så kommer de att sätta igång fullständigt laglösa pogromer mot makten ... "Hyde Park" var ingen överloppsgärning, utan ett nödvändigt övningsfält och en skola för de demokratiska tendensernas framväxt i samhället (Rjabov I988).

Samtidigt med gatudemonstrationskampanjen 1988 gjordes de första försöken att konsolidera oppositionsrörelsens olika strömningar (inom ramarna för den allmändemokratiska inriktningen). Ett samordnat "samhällsmandat" för de sociala rörelserna antogs inför SUKP:s nittonde partikonferens, i vilken det slogs fast: 
Partiet ska omformas från en organisation som styr "i folkets namn" med hjälp av en urartad kast av "partokrater" till en verklig politisk organisation; till den ändan måste det fullständigt berövas alla maktfunktioner som kan överföras till de statliga råden och styrelseorganen vilket också bör avspegla sig i partilagen. Konstitutionens sjätte paragraf måste ändras på motsvarande sätt [...] Makten måste fullt ut överföras till sovjeterna [...] Att skapa ett sant självstyre bör i den demokratiska socialismens anda betraktas som reformens huvuduppgift (Ob̌̌čestvennyj nakaz ... 1988).

Karakteristiskt nog förenades de liberalt-västtillvända och de socialistiskt inriktade ideologerna kring punkten om att tillintetgöra SUKP:s maktmonopol. Men försöket att skapa en bredare sammanslutning, "Folkfronten", slutade med en splittring av Moskvas informella politiska grupper redan den 3 juli 1988 .

\section{Den obeväpnade revolutionen: ett postindustriellt perspektiv}

Bedömningen av händelserna under åttiotalets slut och nittiotalets början är ännu föremål för diskussion. För anhängarna av det system som fanns i Sovjetunionen är dessa händelser "kontrarevolutionära" och till och med "reaktionära" (jfr Ziuganov 20II). Men kontrarevolutionen och revolutionen går hand i hand - den ena är otänkbar utan den andra. Den ekonomiska nedgången som liksom vittnar om en reaktionspolitik är till betydande - om inte övervägande - del en konsekvens av revolutionen. Samtidigt kan man framhäva ett antal kännetecken som inte bara förenar "klassiska" utan även andra typer av revolutioner.

I den givna diskussionskontexten är en revolution en sociopolitisk konflikt, det vill säga en konflikt som involverar breda samhällslager, en social rörelse - till skillnad från en vanlig kupp, men också den politiska eliten (till skillnad från ett vanligt uppror som antingen genomförs genom att man splittrar den existerande makteliten, eller genom att man byter ut den, eller genom att den väsentligen kompletteras med företrädare för andra samhällslager). Ett viktigt kännetecken på en revolution (till skillnad från en lokal revolt) är en splittring som omfattar hela samhället (med allnationell karaktär, där en nation finns). En revolution 
förutsätter också att en eller flera parter i konflikten eftersträvar att förändra hela samhällsstrukturen, de systembildande principerna. Det rör sig långt ifrån alltid om ägandeförhållandena. I regel rör det sig om principerna för hur en elit, exempelvis en "nomenklatura", formeras eller om innehavet av privat egendom.

En revolution är en social skapelse, den övervinner de begränsningar som är förknippade med de befintliga institutionerna för att lösa motsättningar och fatta beslut. Revolutionen strävar efter att förändra "spelreglerna”. Den förnekar den rådande legitimiteten och lutar sig ibland mot en tidigare legitimitetstradition, som den ärorika revolutionen $\mathrm{i}$ England. Därför är revolutionshandlingar till övervägande del illegala och icke-institutionella. Revolutionen låter sig varken begränsas av de existerande institutionerna eller av lagen, vilket ibland utmynnar i en våldsam konfrontation. Sålunda kan man i korthet karakterisera revolutionen som en sociopolitisk konfrontation som handlar om principerna för hur samhället ska organiseras och som övervinner den rådande legitimiteten genom ett förlopp av socialt "masskapande".

Under andra hälften av 1900-talet var den systembildande principen i Ryssland och Sovjetunionen formerandet av eliten, partiets och byråkratins (nomenklaturans) maktmonopol, vilka framstod som "siamesiska tvillingar". Efter att ha känt att samhället inte var inrättat "som det borde", gick människomassorna ut på gatorna och dikterade sina "spelregler" för makthavarna. Jag vill hävda att händelserna I988-1993 vad gäller kämpaglöd och gatudemonstrationernas masskaraktär inte står revolutionerna 1905-1907 efter, och vad gäller förändringarnas djupverkan, så överträffar de dessa. Efter att de ekonomiska reformerna alltså hamnat i en återvändsgränd, var det som tog sin början I 988 just en revolution. De informella grupperna, som verkade illegalt, på trots med lagstiftningen om protestmöten, drog in breda massor av stadsbefolkningarna i oppositionsrörelsen, och skärpte konflikterna inom det styrande partiets led. På så vis skapades 1988-1989 alla kriterier för en revolution i Sovjetunionen.

Vad var det då för en revolution? Vilka var dess sociala aktörer? Ordet "demokratisk" är alltför abstrakt, och det uppnåddes aldrig i Ryssland någon riktig demokrati. Borgerlig? Men liberalerna (i deras egen bemär- 
kelse av ordet, det vill säga anhängare av det kapitalistiska systemet) var inte dominerande i samhällsrörelsen fram till I989. Som inflytelserika krafter blev de kapitalistiska kraven egentligen inte framträdande förrän I990-199I, och kapitalet självt var ännu svagt fram till 1992 - det var just då som det höll på att växa fram. Det var fortfarande alltför tidigt för detta att spela "hegemonirollen" för revolutionen. Fram till 1989-1990 hade inte ens kooperativen fått någon kapitalistisk karaktär än. Sålunda kan man tala om en borgerlig fas av revolutionen först från 1990-I99I. Och hurdan var då den föregående etappens karaktär?

Bedömer man denna revolutionsetapp med utgångspunkt i det samhällsskikt som ledarna ("hegemonigivarna”) tillhörde, så är det intelligentian som hamnar i uppmärksamhetens centrum. Den är alltid problematisk - den sätter igång många rörelser och utvecklar idéer hämtade från flera samhällsskikt. Ibland finns det inte heller någon "klass" än (i bemärkelsen av revolutionär social aktör), och intelligentian förklarar en sådan fortfarande genom de element den är sammansatt av, att de är en klass med sina solidariska intressen. En medvetenhet om gemensamma intressen och formerandet av klassorganisationer visar sig vara ett nödvändigt villkor för att skapa en reell klasstruktur. Så var det när de före detta bönderna och hantverkarna förenades till den industriella arbetarklassen i slutet av I80o-talet. Arbetarklassen var en instabil massa utan fackliga och andra sociala arbetarorganisationer innan socialisterna började agitera och klargöra för människan att hon inte längre var någon bonde, som temporärt vistades i staden, utan en proletär som måste stå upp för sina nya, proletära intressen, vilka inte låg i någon övergiven jordlott på landet, utan här - i staden, på fabriken, i den industriella och sociala lagstiftningen (Šubin 2007). Ett likadant problem uppstod när man skulle riva ner sovjetsamhällets sociala strukturer på 1980-talet. När man förenar intelligentians idéer med intressena hos personer från olika socialgrupper från det föregående samhället så ger detta upphov till en ny klassolidaritet, till en medvetenhet om en ny gemenskap av ömsesidiga intressen. Så började också en ny förståelse av den nya modellen för social stratifikation uppkomma. Men en växling av "klassmodeller" kräver tid. Det av de nya klassintressena som konsolideras snabbast och som förmår finna en kompromiss med de gamla samhällsskikten, kommer också att utgå med 
segern i den givna revolutionen och definiera den variant av social organisation som landet ska tillämpa under de kommande årtiondena. Det fanns ett antal möjliga varianter på utfall här.

De liberala organisationerna gjorde sig till talespersoner för de kapitalistiska reformerna och samhällslagren (från småkapitalet till det oligarkiska kapitalet). Under 1987-1989 stöttes dessa idéer bort av samhället, och den demokratiska socialismen dominerade frihetsrörelsen. Först 1989-I99I övergick intelligentians övre skikt och en del av nomenklaturan till att stödja de liberalkapitalistiska värderingarna. Denna oväntade manöver ledde till en plötslig förändring av kraftförhållandena, den borgerliga tendensens resurser inom revolutionen fick överhanden. Socialisterna led ett nederlag.

Var den informella rörelsens karaktär sådan att anhängarna av kapitalismens liberala åsikter inte kunde få överhanden så länge den var i opposition? Om man betraktar händelserna i slutet av 1980-talet ur ett vitt formeringsperspektiv så blir de jämförbara med 1960-talet i västländerna. En fullkomlig övergång från det traditionella till det industriella samhället hade uppnåtts. Industrisamhällets och välfärdsstatens uppåtgående utveckling hade nått sitt krön, nedgången närmar sig, en övergång till det nästföljande formeringstillståndet. Det är just under sådana perioder som de revolutioner inträffar som inom den marxistiska traditionen har fått förledet "tidig-". De "tidigkapitalistiska" revolutionerna under I500- och I600-talen, exempelvis. De skapade ingen kapitalism, utan fungerade som startskott i "kapplöpningen" mot den.

"Det vilda sextiotalet" i väst och de informella rörelsernas etapp i den sovjetiska revolutionen är båda "tidiga" revolutioner. De skapar inte något nytt system utan bara sprider eller sår det nya. De inleder den långa marschen mot det nya samhället. Till vilket samhälle tänkte man sig då denna övergång? Vilket stadium i samhällsutvecklingen följer på industrisamhället? Detta problem, som uppställts i arbeten av Boris Vyšeslavcev (2006), Daniel Bell (1990), Alvin Toffler (1999) och andra samhällstänkare, var även några av de informella medvetna om. I januari I989 diskuterades det av mig i artikeln ”En värld på väg mot anarki” som publicerades i Obšcina (Gemenskaps tidskrift). I enlighet med ett förslag från Charkovdelegaten Rudomaha ingick sedan artikelns formuleringar 


\section{i "Anarkosyndikalistiska konfederationens" (Konfederacija anarcho- sindikalistov) program:}

I världens utvecklade länder börjar den mest väsentliga indelningen av arbetet i intellektuellt och fysiskt att upplösas. Datarevolutionen skapar principiellt mer fullkomliga kommunikationsmedel, överensstämmelse mellan olika sociala intressen överflödiggör slutligen den hierarkiska tjänstemannaapparaten, som skapats för insamling och bearbetning av information. Förstörelsen av myndigheternas informationsceller utvidgar informationsfrihetens (anarkins) sfär och drar in alla befolkningsskikt i den skapande arbetssfären [...] De byråkratiska maskinernas oförmåga att hantera mänsklighetens samtida problem, och framför allt miljöproblemet, leder till att det partiparlamentariska systemet förlorar i auktoritet [...] Datarevolutionen upplöser samhällets hierarki även på företagsnivå, en maskinell styrning tränger alltmer undan en mänsklig styrning och likviderar den snäva specialiseringen. Men datorerna i sig är inte i stånd att läsa den samtida produktionens problem - de är bara verktyg i människans händer. Motsättningarna mellan olika intressen på företagen hindrar det fria informationsutbytet, som de jämlika parterna kan använda mot varandra. Detta uppreser ofta oöverkomliga hinder på vägen mot att produktionen utvecklas.

Utvägen ligger i de omedelbara tillverkarnas deltagande i såväl tillväxten, som i antagandet av beslut inom produktionen. Arbetarrörelsen i väst under 1950I960-talen fick en väsentlig förskjutning i den riktningen och förde företagen nära intill självstyrelsens gräns.

[...] De icke-partibundna medborgarinitiativen får allt större styrka och eftersträvar decentralisering, maktspridning och territoriell avspecialisering, decentralisering av ekonomin. Detta motsvarar de objektiva ekonomiska processerna som blev framträdande under 1950- och 1960-talen. Med stöd av den rika erfarenheten av lokalt självstyre och den globala demilitariseringsprocessen, blir de icke-partibundna rörelserna en kraft som är i stånd att förverkliga de objektiva premisserna för detta samhälles uppkomst, som teoretiker av olika inriktningar kallar anarki, kommunism, ett postindustriellt och informationsburet samhälle.

Men detta samhälles uppkomst är inte ofrånkomlig. Ett motstånd från byråkratin kan fördröja dess tillblivelse så pass mycket att mänskligheten inte lyckas avvärja den ekologiska och sociopolitiska katastrofen. I så måtto beror världens öde på varje människas individuella val (Šubin 1989).

Här märks inflytandet från västliga postindustriella teorier, men med en viktig skillnad: det västliga postindustriella tänkandet härleder i regel formerandet av nya samhällsrelationer ur teknikutvecklingen, samtidigt som det faktiskt kan förhålla sig tvärtom - att teknikutvecklingen har 
sitt ursprung i en förändring av den sociala strukturen - ur den sociala efterfrågan på dessa teknologier. Datorerna dök upp redan på i940-talet, men den sociala efterfrågan på kraftfulla maskiner som betjänade statens och storindustrins intressen fanns ännu varken i Sovjetunionen eller i USA. Det var först efter det "stormiga" sextiotalet, under vilket de horisontella samhällsstrukturerna hade stärkts, som persondatorernas och den nätverksburna informationsteknologins epok var kommen. Detta uppmärksammar Obščina-artikeln: teknologierna kan inte i sig lösa de sociala problemen. Gemenskap-ideologins påtagliga pacifism kan delvis förklaras med kontexten i det "nya tänkandets" epok, med en förhoppning om att övervinna splittringen i världen, ${ }^{9}$ men är också delvis en principiell konsekvens av synen på utsikterna till utveckling i världen - det postindustriella samhället är globalt och extraterritoriellt, staten förlorar kontrollen över befolkningen, vi dras in i de globala nätverksstrukturerna. Dessa horisontella strukturer framträdde i Sovjetunionen under loppet av perestrojkan och skapade en efterfrågan på införandet av persondatorer, och inte tvärtom.

Vad är då kärnan i de nya, postindustriella sociala relationerna som kvalitativt skiljer dem från de industriella? Den industriella strukturen (industrialismen) var ett system av sociala relationer som grundade sig på innovationer vilka tryggats genom standardisering och snäv specialisering och ett vertikalt system av arbetsstyrning. Priset för minoritetens, elitens, kreativitet är separerandet från det stora flertalets stränga specialisering och att arbetaren är tydligt underordnad chefen; annars kan det industriella samhället helt enkelt inte fungera, på samma sätt som produkten av en specialiserad arbetares verksamhet måste vara standardiserad och passa underleverantörens produkt. På ett liknande sätt hade också styrelsesystem byggts upp i det industrialiserade samhället. Dessa hade en byråkratisk karaktär till och med i demokratiska stater och privata organisationer.

9. För detaljer om den sovjetiska revolutionens utrikespolitiska kontext, se Šubin (2005), om utländska krafters inflytande på oppositionen, se Šubin (2006). Slutsatsen av analysen av detta material består i att såväl perestrojkan som oppositionsrörelsen hade övervägande inrikespolitiska och inhemska sociala orsaker och motiv, inflytandet från den utrikespolitiska situationen var en sekundär faktor. 
De nya relationerna, som principiellt skiljer sig från industrialismens, är inte baserade på styrning ("vertikala förbindelser", en överhetsrelation), utan på överenskommelser, koordinationer ("horisontella förbindelser", jämbördiga relationer) av de skapande arbetare som i sig förenar de tidigare från varandra åtskilda styrelsefunktionerna (självstyret), skapandet och förverkligandet av projektet (det egna arbetet). Det mogna industrisamhället alstrade sin egen dödgrävare - sådana skapande arbetares nätverksstrukturer och den nya klass som skiljer sig från proletariatet och borgerligheten genom att ha överkommit indelningen i en skapande och en styrande elit och en verkställande majoritet. Men för att den nya strukturen ska kunna utvecklas behövs sociala förutsättningar: garantier för självstyre och för arbetarkollektivens skapande produktionsverksamhet, ett samhälleligt och statligt understöd för att skapa en nödvändig infrastruktur som står i samklang med rättssystemet etc.

Detta problem med övergången till det postindustriella ("informations-", det "kreativa", det "horisontella", "nätverks-", det "modellerande" - flera benämningar är möjliga) samhället var varken Michail Gorbatjovs manskap eller flertalet samhällsrörelser medvetna om. I Gorbatjovs och den demokratiska socialismens anhängares tal 1986-1989 kan man bara finna enskilda inslag i den övergripande bilden ("ett påskyndat vetenskapligt och teknologiskt framsteg", "produktionssjälvstyre", "den mänskliga faktorn”). Oförmågan att förstå reformernas inriktning, vilken behövdes för att man skulle ta sig över den vetenskapliga och teknologiska barriären, var det som förutbestämde perestrojkans nederlag. Men när man till sist började inse innebörden av detta problem var samhället redan fullt upptaget med att störta det existerande systemet, utan någon klar föreställning om vad man skulle ersätta det med.

Redan innan en stor mängd persondatorer dök upp i Sovjetunionen blev ett nätverk av informella politiska grupper bärare av de nya horisontella relationerna. Men det var inte tillräckligt utvecklat och stabilt för att stå emot trycket från de borgerligt-byråkratiska krafterna som inriktade sig på fördelningen av den statliga egendomen och Sovjetunionens territorium.

Någon enhetlig benämning på det postindustriella samhället finns inte (benämningen "postindustriellt" visar bara på att ett sådant samhälle 
kvalitativt måste skilja sig från såväl det industriella som från det traditionellt agrara). Benämningen "informationssamhälle" är inte helt lyckat eftersom informationsföden spelar en viktig roll i utvecklingen av varje mänskligt samhälle. Men den nya klass, vars formerande jag har diskuterat ovan, fungerar verkligen företrädesvis inom informationsflödenas sfär, vilka påverkar den materiella produktionen. När man karakteriserar denna klass är det inte bara viktigt att ta hänsyn till dess verksamhets tilllämpningsområde (vilket kan visa sig vara temporärt), utan också till den struktur som precis motsvarar de informellas horisontella och kreativa organisation. Informationsmässigt och informellt - inofficiellt. De nya medelklasserna, som växte fram inom intelligentian och andra skikt av det sovjetiska samhället, var informella. Kanske kommer de i framtiden att bilda en egen klass - informelliatet. Denna framväxt påbörjades redan under perestrojkan, men den avbröts av övergången till privatisering, och inte av utvecklingen av industriella relationer. Samhället slogs tillbaka från den barriär som det försökte inta. Detta är inte sällan resultatet av tidiga revolutioner. I detta avseende kan man också kalla den sovjetiska revolutionen av modell 1988-1990 för en tidig informationsrevolution (Šubin 2005). Detta var en uppgångsfas för det civila samhället när idéer som stod i samklang med de postindustriella målsättningarna genljöd såväl på de informella gruppernas protestmöten som i partireformatorernas tal. Det var också en uppgångsfas för revolutionen som först när Sovjetunionen började falla sönder I99I övergick i en nedgångsfas. Men denna ursprungsimpuls är en ofullständig erfarenhet. Desto viktigare är det att känna och ta hänsyn till den inför nästföljande framryckning in i framtiden.

\section{Avslutning: utbytta milstolpar}

Demokratirörelserna under åren 1988-I990, till vilka även den organiserade arbetarrörelsen (framför allt gruvarbetarna) fogade sig 1989, antog de obetydliga "intellektuella" organisationernas slagord: rättigheter och friheter, enpartisystemets avskaffande, social rättvisa, självstyre, regionernas självständighet etc. De som genererade dessa idéer, som sedan erkändes av samhällets demokratiska sektor, var de informella grupperna 
Gemenskap, Perestrojkaklubben (både moderater och radikaler), Demokratiska förbundet, Medborgerlig värdighet (med en majoritet liberaler) med flera. Under andra halvan av 1980-talet lade dessa grupper fram idéer som därefter fick understöd av "den breda allmänheten". De öppna ideologiska diskussionerna som de informella politiska grupperna förde inbördes och med företrädare för de officiella strukturerna, införde spontant den politiska pluralismen i landet.

Under 1989-1990 blev det uppenbart för den mest dynamiska delen av nomenklaturan att förverkligandet av dess målsättning (att hålla sig kvar vid makten och att tillskansa sig egendom) var omöjlig utan att man bytte ut de värderingar och myter som statsideologin grundades på. Denna del av makteliten slog sig då ihop med statusintelligentian. Att "perestrojkans byggmästare" var kända tillförsäkrade dem tillgång till massmedierna och gav de "officiella" liberalerna möjlighet att - inte så mycket ideologiskt som organisatoriskt - ställa sig i spetsen för frihetsrörelsen. De mest framträdande aktörerna i det liberala lägret lämnade SUKP först i juni 1990, efter att enpartisystemet, nu även de jure och under trycket av massdemonstrationerna, hade avskaffats i februari samma år.

En av de faktorer som försvårade den liberala nomenklaturans övergång till oppositionen mot SUKP var att de framträdande liberalerna under åren 1988-1989 saknade en egen partiapparat. "Perestrojkans byggmästare" var allierade med men inte ledare för de informella politiska grupperna, vilka fattade sina beslut självständigt. De informella organisationernas handlingar utnyttjades naturligtvis av "sextiotalisterna" ${ }^{\text {ıо }}$, inklusive liberalerna i ledningen för SUKP. Men även de informella grupperna fattade varje gång beslut om vilken grupp i toppskikten de skulle och inte skulle stödja.

Först efter valen till folkkongressen 1989 övergick ledarpositionen i demokratirörelsen successivt till Interregionala delegatgruppen (IDG) vilken till sin största del bestod av partiliberaler. Då uppkom också vad som kallats "demokraternas ständiga partiapparat". Men för att stärka

Io. "Sextiotalisterna" (shestidesiatniki) kallades de tidiga reformister inom kommunistpartiet som redan på I960-talet höjde rösten för reformer av systemet som förebådade perestrojkan. Red. anm. 
sin kontroll över de alltmer omfattande medborgarrörelserna var ledarna för IDG tvungna att upprepa de slagord som hade tagits fram av dissidenterna och de informella grupperna. "Egendomen åt folket! Jorden åt bönderna! Fabrikerna åt de arbetande! All makt åt råden!”, sade man i sina appeller till en grupp delegater och uppmanade dem att genomföra en politisk strejk den II december 1989. Alla de ledare som hade skrivit på denna appell (med undantag för Andrej Sacharov som snart avled) skulle efter ett par år bli glödande motståndare till precis dessa slagord. Men I989 var IDG, som innehade parlamentets talarstol, fortfarande språkrör för medborgarrörelsen, vilken under dessa år företräddes av hundratals informella organisationer och samhällsrörelser, självstyrande strejkkommittéer och andra direktdemokratiska institutioner. Företrädarna för denna rörelse fortsatte att ha en väsentlig inverkan på det demokratiska lägrets politik fram till I990, samt under krisperioden - fram till augusti I99I.

Mot mitten av år 1990 befästes pluralismens värderingar och den idémässiga toleransen, de medborgerliga friheterna och byggandet av samhället underifrån i det medborgerliga medvetandet i Sovjetunionens större republiker. I Ryssland uppkom genom en mångfald av ömsesidiga kontakter ett lagligt och enat civilsamhälle som bestod av statsoberoende ekonomiska, samhälleliga, fackliga och informationsmässiga organisationer. Embryon till en oavhängig press bildades, styrelsesystemet blev polycentriskt - de lokala rådens makt återupprättades. Som ett resultat av parlamentsvalen 1990 skapades en av SUKP oberoende representativ makt, varpå även SUKP förlorade sin karaktär av totalitär institution och omvandlades till ett av de två större partierna (det andra blev rörelsen Demokratiska Ryssland som hade vuxit fram ur de informella politiska rörelserna, nya partier och IDG). Civilsamhällets angrepp på den auktoritära kommunistregimen kröntes med framgång. Men Sovjetunionen höll sig vid liv i ytterligare ett och ett halvt år.

Som såväl konservativt-kommunistiska som radikalt-liberala författare anmärker främjades undanträngandet av SUKP - det kommunistparti som därmed förlorade maktmonopolet och som "hade varit den huvudsakliga cementerande kraften i Sovjetunionen" - från de styrande strukturerna av "att Sovjetunionens sammanbrott antog en galoppe- 
rande karaktär” (Sogrin 1994, s. IOI). Men även här måste man påpeka att kopplingen mellan försvagningen av SUKP:s position och Sovjetunionens sammanbrott inte är så rätlinjig. För det första så gjorde inte kommuniststrukturernas praktiskt taget fullständiga bibehållande av makten i Kazakstan, Turkmenistan och Uzbekistan att dessa republiker blev ett bålverk för Gorbatjovs centralmakt. Sovjetunionens sammanbrott fick i hög grad sin "galopperande karaktär" på grund av motsägelserna inom den kommunistiska byråkratin som "cementerande kraft". Och dessa motsägelser uppkom inte i och med perestrojkan. De växte till under hela Brezjnevs "stagnationsperiod". Under dessa omständigheter blev perestrojkan inte en orsak utan en signal till rivaliteten mellan och "autonomiseringen" av partibyråkratins klaner. Roj Medvedev tillgriper följande bild för att bevisa sambandet mellan Sovjetunionens och SUKP:s sammanbrott: partiet "förblev den sovjetiska statens huvudsakliga bärande konstruktion" (Medvedev 2003, s. 253). Men under 1980talet var inte SUKP längre så mycket en bärande konstruktion som en huvudbörda som tyngde ner de andra konstruktionerna och därtill förstörde dem under det att den själv förstördes.

Därför blev just det att befria samhället från en så farlig "ledande och styrande kraft" vägen mot dess räddning. Men även denna väg hade sina brister - civilsamhället höll just på att formeras och Gorbatjovs reformer skapade inte något annat alternativt koordinatsystem för SUKP att navigera efter. Det beslut som fattades på den nittonde partikonferensen I988 om att kombinera posterna som parti- och rådsledare ledde till att de administrativa kadrerna och de mest aktiva partikadrerna överfördes till rådsstrukturerna. Detta bidrog till att motsättningarna skärptes inom partieliten (en del av den passerade inte urvalet till valen), till att de administrativa kadrerna partiellt förnyades och till att dess nomenklaturastruktur bevarades. Samtidigt som Gorbatjov satsade på råden formerade han inget koordinationssystem för rådsorganen och för presidentmaktens strukturer. Det nya rådssystemet formerade sig faktiskt i opposition till presidenten, vilket under de omständigheter som rådde I990-I99I på inget vis gynnade statens konsolidering.

I frånvaro av en kraft som inte bara skulle kunna tränga undan de kommunistiska strukturerna, utan också ersätta dess styrelsefunktioner, 
fortsatte de lokala byråkratiklanerna att stärka sin ställning trots enskilda förluster till "demokraterna”. Svaret på "demokraternas" uppträdande blev att en del av byråkratin övergick till "demokraternas" och de nationella rörelsernas sida. Problemet låg i vem som skulle få "hela folkets" egendom och under vilka villkor detta skulle ske. Kampen om makten som en position vilken fastställde hur egendomen skulle fördelas blev grunden till förbundet, i kampen mot centralmakten, mellan de nationella eliterna och ledarna för den "demokratiska" rörelsen, vilken även inbegrep en del av det informella aktivistkollektivet. De informella politiska grupper som inte "kom till makten" kom att utgöra basen för civilsamhället i det moderna Ryssland. Som så ofta i historien slutade även de informella gruppernas kamp med såväl en delseger som en delförlust. Fienden var krossad men kvar stod frågan: "Var det detta vi kämpade för?" De informella grupperna var avantgardet i den armé som besegrade den kommunistiska regimen. Men de underordnade sig inte staben för denna armé - de var perestrojkans partisaner, dess friskaror. De hade andra mål än Jeltsins armé.

Sovjetunionens sammanbrott och "chockterapin" i början av 1990talet ledde till betydande förändringar även i det civila samhällets struktur. Det professionaliserades, minskade kraftigt i antal organisationer och aktiva, samt, i början av 2000-talet, även i inflytande. Men som den samhälleliga väckelsen under åren 20II-20I2 har visat, är de situationer som uppkom under perestrojkaperioden i de flesta fall fortfarande modeller för den samtida samhällsrörelsen. Detta innebär att den ryska civila politiska kulturen, när den väl hade uppkommit under perestrojkan, sedan reproducerades i slutet av 1990- och i början av 2000-talet. Detta berör framför allt involverandet av en sådan faktor som internet - ett mer effektivt och massomfattande kommunikationsmedel än samizdat ${ }^{\text {II }}$. Men även samizdat kunde fylla funktionen av ett "långsamt internet". Samhället har väsentligen förändrats sedan 1980-talet. Samtidigt har denna förändring ur värderingssynvinkel inte varit allmängiltig. Liksom på I980-talet eftersträvar samhällsrörelsen i dag att stå emot tjänstemännens maktfullkomlighet, korruptionen, det otillräckliga folkväldet, den sänkta

II. En icke-officiell produktion och distribution av texter som syftade till att undvika censuren i Sovjetunionen. Red. anm. 
levnadsnivån och andra omständigheter som har fört erfarenheterna från det sena Sovjetunionen närmare situationen i den samtida Ryska federationen. De informella politiska grupperna gjorde civilsamhället till en varaktig faktor i landets samhällsliv. Civilsamhället kan vara starkare, som i början 1990-talet, eller svagare, som i början av 2000-talet, men det har bevarats och ger vårt land en chans att passera mellan statsauktoritarismens Skylla och kompradorkapitalismens Karybdis i den postindustriella världen.

\section{Översättning: Pontus Lindgren}

\section{Referenser}

Bell, D. (I990) Grjaduščee postindustrial'noe obščestvo. Opyt social'nogo prognozirovanija, Moskva: Academia.

Chronika obščestvennogo dviženija, nr 5-6 (1988).

Igrunov, V. (1989) "O neformal'nych političeskich klubach Moskvy", Problemy Vostočnoj Evropy, 27-28: 60-82.

Jušenkov, S. N. (red.) (1990) Neformaly. Social'nye iniciativy, Moskva: Moskovskij rabočij. Jušenkov, S. N. (I99I) "Proščaj Gaid-park na Puškinskoj", i S. Mitrochina (red.), Chronograf-go, Moskva: Moskovskij rabočij.

Lenin, V. (I968 [1912]) "Pamjati Gercena”, i Polnoe sobranije sočinenij, vol. 2I, Moskva: Izdatel'stvo političeskoj literatury.

Medvedev, R. (2003) Soveckij Sojuz. Poslednij god žizni, Moskva: Prava čeloveka.

Mitrochin, S. (I988) "Roždenie 'Gajd-parka”, Chronograf, 7.

Obščstvennyj nakaz XIX partijnoj konferencii KPSS, 5 i I2 ijunja I988 (I988)

URL: http://www.Iooodokumente.de/index.html/index.html?c=dokument_ ru\&dokument=oor8_auf\&object=translation\&l=ru (2I december 2015)

Rjabov, P. (1988) Vylazka iz podpol’ja, ili socialističeskij pljuralizm mnenij na ploščadjah Moskvy (razmyšlenija ob itogah majsko-ijon'skoj mitingovoj kampanii), från A. V. Šubins privata arkiv, juni-augusti 1988.

Sogrin, V. (1994) Političeskaja istorija sovremennoj Rossii. 1985-1994. Ot Gorbačëva do Jel'cina, Moskva: Progress-Akademia.

Šubin, A. V. (1989) "Mir na puti k anarhii”, Obščina, 30: 17-20.

Šubin, A. V. (2005) Paradoksy Perestrojki. Upuščennyj šans SSSR, Moskva: Veče.

Šubin, A. V. (2006) Predannaja demokratija. SSSR i neformaly 1986-1989, Moskva: Evropa.

Šubin, A. V. (2007) Socializm. "Zolotoj vek" teorii, Moskva: Izdatel'stvo Novoe Literaturnoe Obozrenije.

Šubin, A. V. (2008) Dissidenty, neformaly i svoboda v SSSR, Moskva: Veče.

Toffler, A. (1999) Tretja volna, Moskva: Izdatel'stvo AST. 


\section{ŠUBIN | DEN SENSOVJETISKA SOCIALA MOBILISERINGEN}

Vyšeslavcev, B. P. (2006) "Krizis industrial'noj kul'tury", i B. P. Vyšeslavcev (red.), Izbrannye sočinenija, Moskva: Astrel'.

Ziuganov, G. (20II) Krach kontrrevoljucii, Moskva: Izdatel'stvo ITKR.

Zolotarëv, V. (2005) Pervye neformaly i politika Sovetskogo Sojuza.

URL: http://www.igrunov.ru/vin/vchk-vin-n_histor/remen/III3II7752.html (2I december 20I5) 


\section{Moderna klassiker}

\section{Jürgen Habermas \\ Borgerlig offentlighet}

\section{Arkiv förlag}

Jürgen Habermas magnifika genombrottsverk Borgerlig offentlighet (Strukturwandel der Öffentlichkeit) från 1962 är en brett upplagd historisk och sociologisk undersökning av hur den tidiga borgerligheten skapar den moderna åtskillnaden mellan "privat" och "offentligt", varvid offentligheten tilldelas rollen som kritisk granskare av statens verksamhet. Habermas visar på ett fascinerande sätt hur kapitalismens utveckling och de samhälleliga motsättningarna undergräver möjligheterna till en sådan kritisk kontroll. Samtidigt förskjuts de tidigare gränserna mellan "privat" och "offentligt" på nya och oväntade sätt.

Arkiv förlag 2003, 300 sidor 